\title{
A Single Large Dose of Vitamin D Could be Used as a Means of Coronavirus Disease 2019 Prevention and Treatment
}

This article was published in the following Dove Press journal: Drug Design, Development and Therapy

\section{Guoqiang Liu (D) \\ Tianpei Hong (D) \\ Jin Yang (D)}

Department of Endocrinology and Metabolism, Peking University Third Hospital, Beijing 100191, People's

Republic of China
Correspondence: Jin Yang

Tel +86-10-82266722

Email yangjin@bjmu.edu.cn

\begin{abstract}
There is no specific and effective medication for coronavirus disease 2019 (COVID-19), and avaccine is not available in recent months. Here, we hypothesize that a single large dose of vitamin D (Vit D) could be an option for trial in COVID-19. Vit $\mathrm{D}$ deficiency or insufficiency is very common in the general population as well as in patients with COVID-19. It has been shown that low Vit D level is associated with viral infection, and Vit D supplementation is beneficial for people infected with viruses, such as HIV and hepatitis $\mathrm{C}$ virus. Although COVID-19 is a respiratory disease, the morbidity and mortality of this disease are driven by coagulopathy. Clinical studies have shown that Vit D can exert anticoagulant effects. Vit D, a lipid-soluble vitamin, can be administered as a draught. Vit $\mathrm{D}$ supplementation is safe and has rare toxic events. In addition, the cost of Vit D is fairly low. Based on these observations, we speculate that a single dose of 300,000 IU Vit D may have a role in the prevention and treatment of COVID-19.
\end{abstract}

Keywords: vitamin D, large dose, coronavirus disease 2019

\section{Introduction}

Coronavirus disease 2019 (COVID-19) caused by severe acute respiratory syndrome coronavirus 2 (SARS-CoV-2) is an unprecedented challenge for the whole world and modern medicine. According to reports of the World Health Organization (WHO), incidence and prevalence of this virus infection is still increasing worldwide, and as of August 5, 2020, more than 18 million people have been affected, including more than 696 thousand deaths. Since COVID-19 is a completely new disease, no specific drug has been proven to be efficacious and safe for treating it at present. ${ }^{1}$ Moreover, vaccine development and clinical application may take years. Therefore, any low-risk treatment is worth trying to help control the global pandemic.

Vitamin D (Vit D) is an essential lipid-soluble vitamin and steroid prohormone. The benefits of Vit D are not limited to the regulation of calcium and phosphorus metabolism and the maintenance of bone health. It has been demonstrated that Vit D deficiency or insufficiency is associated with cardiovascular diseases, ${ }^{2}$ tumors, ${ }^{3}$ respiratory infections, ${ }^{4,5}$ asthma, ${ }^{6,7}$ and other diseases ${ }^{8-11}$ (Table 1). Vit D deficiency is defined as a 25-hydroxyvitamin $\mathrm{D}[25(\mathrm{OH}) \mathrm{D}]$ below $20 \mathrm{ng} / \mathrm{mL}$, insufficiency as a 25(OH)D of 21-29 ng/mL, and sufficiency as a $25(\mathrm{OH}) \mathrm{D}$ of $30-100 \mathrm{ng} / \mathrm{mL} .^{12}$ Epidemiologically, Vit D deficiency or insufficiency has been reported to be very common in all age 
Table I Vitamin D Deficiency or Insufficiency-related Diseases and Disorders

\begin{tabular}{|l|l|}
\hline Category & Related Diseases and Disorders \\
\hline $\begin{array}{l}\text { Cardiovascular } \\
\text { disease }^{2}\end{array}$ & $\begin{array}{l}\text { Heart failure, myocardial infarction, and } \\
\text { ischemic heart disease }\end{array}$ \\
\hline Tumor $^{3}$ & $\begin{array}{l}\text { Colorectal cancer, breast cancer, prostate } \\
\text { cancer, melanoma, lung cancer, and cutaneous } \\
\text { cancers }\end{array}$ \\
\hline $\begin{array}{l}\text { Infectious } \\
\text { diseases,5 }\end{array}$ & Acute respiratory tract infection \\
\hline $\begin{array}{l}\text { Respiratory } \\
\text { disease }^{6,7}\end{array}$ & Asthma \\
\hline $\begin{array}{l}\text { Neuropsychiatric } \\
\text { diseases }\end{array}$ & $\begin{array}{l}\text { Alzheimer's disease, Parkinson's disease, } \\
\text { multiple sclerosis, and schizophrenia }\end{array}$ \\
\hline Dermatosis & Dermatitis, psoriasis, and vitiligo \\
\hline $\begin{array}{l}\text { Metabolic } \\
\text { disease }\end{array}$ & $\begin{array}{l}\text { Obesity, type 2 diabetes mellitus, insulin } \\
\text { resistance }\end{array}$ \\
\hline $\begin{array}{l}\text { Autoimmune } \\
\text { disease }^{11}\end{array}$ & $\begin{array}{l}\text { Systemic lupus erythematosus, iridocyclitis, } \\
\text { Crohn's disease, ulcerative colitis, rheumatoid } \\
\text { arthritis, and polymyalgia rheumatica }\end{array}$ \\
\hline
\end{tabular}

groups. The proportion of Vit D deficiency and insufficiency in Shanghai postmenopausal women in winter is as high as $98 \%{ }^{13}$ A study of males in Beijing also reports that the proportion of Vit D deficiency and insufficiency is $88 \%{ }^{14}$ Likewise, the proportion in pregnant women in winter in the southeastern US is $87.6 \% .{ }^{15}$ The latest study published in July 2020 showed that the mean plasma 25(OH)D level was significantly lower among people who tested positive than negative for COVID-19. ${ }^{16}$ Notably, quarantine would lead to a decreased intake of Vit $\mathrm{D}$ in diet and reduced outdoor sunlight exposure activity. ${ }^{17}$

\section{The Hypotheses}

\section{Antiviral Effect of Vit D}

There is strong evidence that low Vit D level is associated with viral infection and Vit D supplementation is beneficial for people receiving antiviral therapy. Respiratory syncytial virus (RSV) and human metapneumovirus (hMPV) are major causes of illness in hospitalized children. It was reported that Vit D deficiency is commonly detected among RSV and/or hMPV-positive children and is associated with significantly elevated risk of intensive care unit admission and invasive mechanical ventilation. ${ }^{18,19}$
Moreover, Vit D plays a role in the treatment of RNA viruses such as human immunodeficiency virus (HIV) and hepatitis $\mathrm{C}$ virus (HCV). Vit D deficiency is associated with lower absolute $\mathrm{CD} 4^{+} \mathrm{T}$-cell count recovery in HIV-positive patients and Vit D supplementation may improve the $\mathrm{CD} 4{ }^{+} \mathrm{T}$ cell count recovery. ${ }^{20} \mathrm{~A}$ pilot, openlabel, prospective phase 1 clinical trial in HIV-positive patients with Vit D deficiency showed that a single dose of 200,000 IU oral Vit D increased the frequencies of antigen-specific $\mathrm{T}$ cells expressing macrophage inflammatory protein $1 \beta$ (MIP-1 $\beta$ ), an important anti-HIV blocking chemokine. In addition, plasma cathelicidin, a Vit D response gene encoding product with broad antimicrobial activity, was also increased after the treatment. $^{21}$ These results suggested that Vit D supplementation may be a useful adjunct to highly active antiretroviral therapy.

Heightened immune activation and exhaustion drive HIV disease progression and comorbidities. In a recent study, 51 HIV-infected youths, with baseline serum 25(OH)D concentrations $\leq 30 \mathrm{ng} / \mathrm{mL}$, were enrolled and treated by adding three different Vit D doses of 18,000 IU, 60,000 IU and 120,000 IU monthly on a combination antiretroviral therapy. The measured markers $\mathrm{CD} 4$ activation $\left(\mathrm{CD} 4^{+} \mathrm{CD} 38^{+} \mathrm{HLA}-\right.$ $\left.\mathrm{DR}^{+}\right), \mathrm{CD} 8$ activation $\left(\mathrm{CD} 8^{+} \mathrm{CD} 38^{+} \mathrm{HLA}^{\left.-\mathrm{DR}^{+}\right)}\right.$and inflammatory monocytes $\left(\mathrm{CD} 14^{+} \mathrm{CD} 16^{+}\right)$were significantly decreased in the high-dose group. These data suggested that high-dose Vit D supplementation may attenuate immune activation and exhaustion and serve as adjuvant therapy to antiretroviral therapy in HIV-infected people. ${ }^{22}$ Metaanalysis showed that an adequate level of $25(\mathrm{OH}) \mathrm{D}$ was positively associated with the number of $\mathrm{CD}^{+}$cells in HIVinfected individuals. ${ }^{23}$

Similarly, Vit D levels in HCV-infected patients are significantly lower than in healthy subjects. Responders to ribavirin plus pegylated interferon alpha $2 \alpha$ therapy have significantly higher Vit D levels than nonresponders. ${ }^{24}$ It has been demonstrated that Vit D supplementation for 24 weeks combined with conventional therapy significantly improve the virological response in $\mathrm{HCV}$-infected children. ${ }^{25}$

Collectively, the Vit D deficiency might play a role in the development of COVID-19. Vit D can modulate the expression and secretion of type 1 interferon, chemokines (including CXCL8 and CXCL10) and pro-inflammatory cytokines, such as tumor necrosis factor (TNF) and interleukin-6 (IL-6), in human respiratory epithelial cell culture. $^{26}$ Vit D supplementation might have a potential 
role in the antiviral treatment. Therefore, it is reasonable to speculate that Vit D may be useful in the antiviral therapy against SARS-CoV-2 infection.

In addition, both immune dysfunction and cytokine storm play a fundamental role in the development of COVID-19. ${ }^{27}$ It is known that Vit D modulates the function of immune cells, such as $\mathrm{T}$ and B cells, monocytes and dendritic cells, in an interplay between the innate and adaptive immune systems, ${ }^{28}$ and regulates the expression and secretion of cytokines such as TNF and IL- $6 .{ }^{26}$ In terms of these effects on immune system, therapeutic intervention with Vit D might prevent and treat COVID-19.

\section{Anticoagulant Effect of Vit D}

It has been shown that Vit D takes effect on the blood coagulation parameters. In patients with primary ovarian insufficiency, serum Vit D level was inversely correlated with D-dimer. ${ }^{29}$ In a study involving the pregnant women with early stage of preeclampsia, the improvement of serum fibrinogen level and activated partial thromboplastin time after Vit D intervention was better than that of the conventional treatment group. ${ }^{30}$ Moreover, a previous study reported that treatment of Vit D deficiency in patients with thromboembolism resulted in the control of the international normalized ratio with the lower doses of warfarin. ${ }^{31}$

Although COVID-19 is an acute respiratory disease, more and more data have shown that the morbidity and mortality of this disease are driven by coagulopathy, which leads to thromboses, thereby causing multiple system or organ failure and costing enormous medical expense. Recent studies have indicated that severe COVID-19 is associated with a significant coagulopathy that correlates with disease severity in Caucasian patients. $^{32}$ A study carried out in two hospitals in Wuhan, China, enrolled 48 patients critically ill with COVID-19 who received compression ultrasound examinations in the lower extremities, showed that deep venous thrombosis was detected in 41 patients. ${ }^{33}$ According to a study in Wuhan Tongji Hospital, the nonsurvivors revealed significantly higher D-dimer and fibrin degradation product levels, and longer prothrombin time and activated partial thromboplastin time compared with the survivors; $71.4 \%$ of nonsurvivors and $0.6 \%$ survivors meet the criteria of disseminated intravascular coagulopathy. ${ }^{34}$ Anticoagulant therapy mainly with low molecular weight heparin appears to be associated with better prognosis in patients severely ill with COVID-19 meeting sepsis-induced coagulopathy criteria or with markedly elevated D-dimer. ${ }^{35}$

Based on the aforementioned findings, we speculate that Vit D deficiency or insufficiency may be an underlying contributor to coagulopathy associated with COVID19. Vit D can play an anticoagulant role in treating patients severely ill with COVID-19 and preventing mild cases from becoming severe.

\section{Vit D Administration is Convenient and Safe}

Vit $\mathrm{D}$ is a lipid-soluble vitamin, and can be administered as a draught. From our clinical experience in patients with Vit D deficiency or insufficiency, a single dose of 300,000 IU (in one ampulla) is safe. Four weeks after the administration, the serum $25(\mathrm{OH}) \mathrm{D}$ concentration can be elevated to the level of about $60 \mathrm{ng} / \mathrm{mL}$, and all the patients have normal blood calcium levels.

Vit $\mathrm{D}$ supplementation is very safe and Vit $\mathrm{D}$ toxicity is a rare event caused by ingestion of excessively high amounts of Vit D. Most studies in children and adults have suggested that the blood levels need to be above $150 \mathrm{ng} / \mathrm{mL}$ before there is any concern. Therefore, an upper level of $100 \mathrm{ng} / \mathrm{mL}$ provides a safety margin in reducing risk of hypercalcemia. ${ }^{12}$ The cases of Vit D toxicity accompanied by various toxic symptoms have serum 25(OH)D concentrations ranging from 213 to $>640$ $\mathrm{ng} / \mathrm{mL}(533$ to $>1600 \mathrm{nmol} / \mathrm{L}){ }^{36}$

To ensure safety, testing the blood calcium and $25(\mathrm{OH})$ D levels two to four weeks after taking Vit D is needed, but in most cases it is not always necessary.

\section{The Administration of a Single Large Dose of Vit D}

A single dose of 300,000 IU Vit D is taken orally as a draught for general population, outpatients, and inpatients. In fact, a single dose of 300,000 IU Vit D is often administrated to treat the general population or pregnant woman with Vit D deficiency or insufficiency in clinical practice. Moreover, the dose of 300,000 IU was also used in some clinical trials among HIV-infected patients ${ }^{37}$ and rheumatic patients. ${ }^{38}$

For some patients with severe conditions, a dose of 300,000 IU Vit D was often administered via intramuscular injection. ${ }^{39}$ If needed, another dose of 300,000 IU can be administrated after two or three months. 


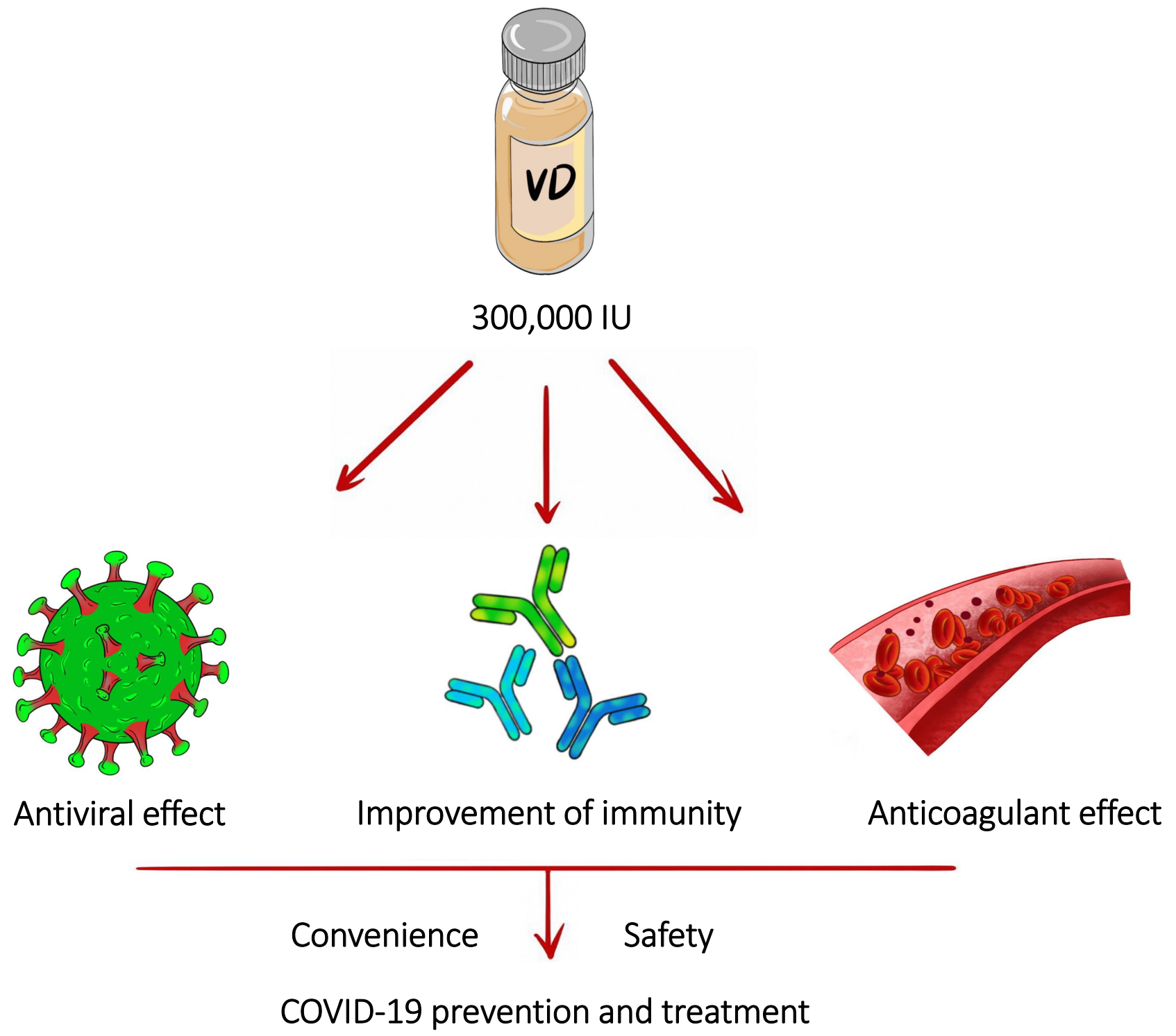

Figure I A single large dose of vitamin D could be used as a means of COVID-19 prevention and treatment.

\section{Clinical Significance}

The pandemic of COVID-19 is raging around the world, there is no specific and effective treatment for the disease, and thea vaccine is not available in recent months. The lowrisk and low-cost administration of Vit D is worth trying to help control the global pandemic and Vit D supplementation is an easily acceptable treatment for people.

\section{Conclusion}

Based on the antiviral and anticoagulant effects of Vit D, as well as its convenience and safety, we hypothesize that a single dose of 300,000 IU of Vit D can be helpful for the treatment or prevention of COVID-19 (Figure 1). It is very necessary to add Vit D to the ongoing treatment trials, especially in the case that no specific medications are available for the treatment of COVID-19.

\section{Dedication}

The authors would like to dedicate this article to WHO and clinicians to help to control the pandemic of COVID-19 by turning this hypothesis with specific recommended dose and protocol into reality or initiating a clinical trial.

\section{Disclosure}

The authors report no conflicts of interest in this work. 


\section{References}

1. Alhazzani W, Møller MH, Arabi YM, et al. Surviving sepsis campaign: guidelines on the management of critically Ill adults with Coronavirus disease 2019 (COVID-19). Crit Care Med. 2020;48(6): e440-e469. doi:10.1097/CCM.0000000000004363

2. Zhang R, Li B, Gao X. Serum 25-hydroxyvitamin D and the risk of cardiovascular disease: dose-response meta-analysis of prospective studies. Am J Clin Nutr. 2017;105(4):810-819. doi:10.3945/ ajcn.116.140392

3. Keum N, Giovannucci E. Vitamin D supplements and cancer incidence and mortality: a meta-analysis. $B r \quad J$ Cancer. 2014;111 (5):976-980. doi:10.1038/bjc.2014.294

4. Martineau AR, Jolliffe DA, Hooper RL. Vitamin D supplementation to prevent acute respiratory tract infections: systematic review and meta-analysis of individual participant data. BMJ. 2017;356:i6583. doi:10.1136/bmj.i6583

5. Zisi D, Challa A, Makis A. The association between vitamin D status and infectious diseases of the respiratory system in infancy and childhood. Hormones (Athens). 2019;18(4):353-363. doi:10.1007/ s42000-019-00155-z

6. Martineau AR, Cates CJ, Urashima M. Vitamin D for the management of asthma. Cochrane Database Syst Rev. 2016;9(9):CD011511.

7. Chawes BL, Bønnelykke K, Stokholm J. Effect of vitamin $\mathrm{D}_{3}$ supplementation during pregnancy on risk of persistent wheeze in the offspring: a randomized clinical trial. JAMA. 2016;315(4):353-361. doi:10.1001/jama.2015.18318

8. Bivona G, Gambino CM, Iacolino G, et al. Vitamin D and the nervous system. Neurol Res. 2019;41(9):827-835. doi:10.1080/ 01616412.2019 .1622872

9. Bergqvist C, Ezzedine K. Vitamin D and the skin: what should a dermatologist know? G Ital Dermatol Venereol. 2019;154 (6):669-680. doi:10.23736/S0392-0488.19.06433-2

10. Sacerdote A, Dave P, Lokshin V, et al. Type 2 diabetes mellitus, insulin resistance, and vitamin D. Curr Diab Rep. 2019;19(10):101. doi:10.1007/s11892-019-1201-y

11. Murdaca G, Tonacci A, Negrini S, et al. Emerging role of vitamin $\mathrm{D}$ in autoimmune diseases: an update on evidence and therapeutic implications. Autoimmun Rev. 2019;18(9):102350. doi:10.1016/j. autrev.2019.102350

12. Michael FH, Neil CB, Heike AB, et al. Endocrine Society. Evaluation, treatment, and prevention of vitamin D deficiency: an Endocrine Society clinical practice guideline. J Clin Endocrinol Metab. 2011;96(7):1911-1930. doi:10.1210/jc.2011-0385

13. Zhang H, Huang Q, Zhang Z, et al. Vitamin D status of postmenopausal women in winter in Shanghai. Chin J Osteoporosis. 2011;17 (1):43-46. (in Chinese).

14. Pei Y, Liu Y, Lu Y, et al. The relationship between the nutritional status of vitamin D and bone turnover in males in a community of Beijing. Chin J Osteoporosis Bone Miner Res. 2013;6(4):308-313. (in Chinese).

15. Chawla D, Daniels JL, Benjamin-Neelon SE, et al. Racial and ethnic differences in predictors of vitamin D among pregnant women in south-eastern USA. J Nutr Sci. 2019;28:e8. doi:10.1017/jns.2019.4

16. Merzon E, Tworowski D, Gorohovski A, et al. Low plasma $25(\mathrm{OH})$ vitamin $\mathrm{D}$ level is associated with increased risk of COVID-19 infection: an Israeli population-based study. FEBS J. 2020. doi:10.1111/febs. 15495

17. Mattioli AV, Sciomer S, Cocchi C, et al. Quarantine during COVID-19 outbreak: changes in diet and physical activity increase the risk of cardiovascular disease. Nutr Metab Cardiovasc Dis. 2020. doi:10.1016/j.numecd.2020.05.020

18. Halasa N, Williams J, Faouri S, et al. Natural history and epidemiology of respiratory syncytial virus infection in the Middle East: Hospital surveillance for children under age two in Jordan. Vaccine. 2015;33(47):6479-6487. doi:10.1016/j.vaccine.2015.08.048
19. Hurwitz JL, Jones BG, Penkert RR, et al. Retinol-binding protein and vitamin D levels are associated with severe outcomes in children hospitalized with lower respiratory tract infection and respiratory syncytial virus or human metapneumovirus detection. $J$ Pediatr. 2017;187:323-327. doi:10.1016/j.jpeds.2017.04.061

20. Ezeamama AE, Guwatudde D, Wang M, et al. Vitamin-D deficiency impairs CD4+ T-cell count recovery rate in HIV-positive adults on highly active antiretroviral therapy: a longitudinal study. Clin Nutr. 2016;35(5):1110-1117. doi:10.1016/j.clnu.2015.08.007

21. Lachmann R, Bevan MA, Kim S, et al. A comparative phase 1 clinical trial to identify anti-infective mechanisms of vitamin $\mathrm{D}$ in people with HIV infection. AIDS. 2015;29(10):1127-1135. doi:10.1097/QAD.0000000000000666

22. Eckard AR, O'Riordan MA, Rosebush JC, et al. A vitamin D supplementation decreases immune activation and exhaustion in HIV-1-infected youth. Antivir Ther. 2018;23(4):315-324. doi:10.3851/IMP3199

23. Teixeira NDSCCA, Pereira BM, Oliveira IKF, et al. Effect of vitamin $\mathrm{D}_{3}$ supplementation on HIV-infected adults: a systematic review vitamin $\mathrm{D}_{3}$ supplementation on HIV-infected adults: a systematic review. Nutr Hosp. 2019;36(5):1205-1212. doi:10.20960/nh.02647

24. Mohamed AA, Sabry NA, Abbassi MM, et al. Vitamin D levels in Egyptian HCV patients (genotype 4) treated with pegylated interferon. Acta Gastroenterol Belg. 2013;76(1):38-44.

25. Eltayeb AA, Abdou MA, Abdel-aal AM, et al. Vitamin D status and viral response to therapy in hepatitis $\mathrm{C}$ infected children. World J Gastroenterol. 2015;21(4):1284-1291. doi:10.3748/wjg.v21.i4.1284

26. Greiller CL, Martineau AR. Modulation of the immune response to respiratory viruses by vitamin D. Nutrients. 2015;7(6):4240-4270. doi:10.3390/nu7064240

27. Jafarzadeh A, Chauhan P, Saha B, et al. Contribution of monocytes and macrophages to the local tissue inflammation and cytokine storm in COVID-19: lessons from SARS and MERS, and potential therapeutic interventions. Life Sci. 2020;257:118102. doi:10.1016/j. lfs. 2020.118102

28. Suaini NH, Zhang Y, Vuillermin PJ, et al. Immune modulation by vitamin D and its relevance to food allergy. Nutrients. 2015;7 (8):6088-6108. doi:10.3390/nu7085271

29. Kebapcilar AG, Kulaksizoglu M, Ipekci SH, et al. Relationship between mean platelet volume and low-grade systemic coagulation with vitamin D deficiency in primary ovarian insufficiency. Arch Gynecol Obstet. 2013;288(1):207-212. doi:10.1007/s00404-0132735-x

30. Yu H, Dai Y, He Y. Effects of vitamin D adjuvant intervention on serum 25(OH)D levels in preeclampsia and blood coagulation. Maternal Child HealthC China. 2019;34(16):3664-3667. (in Chinese).

31. Hejazi ME, Modarresi-Ghazani F, Hamishehkar H, et al. The effect of treatment of vitamin D deficiency on the level of P-selectin and hs-CRP in patients with thromboembolism: a pilot randomized clinical trial. J Clin Pharmacol. 2017;57(1):40-47. doi:10.1002/jcph.774

32. Fogarty H, Townsend L, Ni Cheallaigh C, et al. COVID-19 coagulopathy in caucasian patients. Br J Haematol. 2020;189(6):1044-1049. doi:10.1111/bjh. 16749

33. Ren B, Yan F, Deng Z, et al. Extremely high incidence of lower extremity deep venous thrombosis in 48 patients with severe COVID-19 in Wuhan. Circulation. 2020;142(2):181-183. doi:10.1161/CIRCULATIONAHA.120.047407

34. Tang N, Li D, Wang X, et al. Abnormal coagulation parameters are associated with poor prognosis in patients with novel coronavirus pneumonia. J Thromb Haemost. 2020;18(5):844-847. doi:10.1111/ jth. 14768

35. Tang N, Bai H, Chen X, et al. Anticoagulant treatment is associated with decreased mortality in severe coronavirus disease 2019 patients with coagulopathy. J Thromb Haemost. 2020;18(5):1094-1099. doi: $10.1111 /$ jth. 14817 
36. Hathcock JN, Shao A, Vieth R, et al. Risk assessment for vitamin D. Am J Clin Nutr. 2007;85(1):6-18. doi:10.1093/ajcn/85.1.6

37. Piso RJ, Rothen M, Rothen JP, et al. Per oral substitution with 300,000 IU vitamin D (cholecalciferol) reduces bone turnover markers in HIV-infected patients. BMC Infect Dis. 2013;13:577. doi:10.1186/1471-2334-13-577

38. Von Restorff C, Bischoff-Ferrari HA, Theiler R. High-dose oral vitamin $\mathrm{D}_{3}$ supplementation in rheumatology patients with severe vitamin $\mathrm{D}_{3}$ deficiency. Bone. 2009;45(4):747-749. doi:10.1016/j. bone.2009.06.012
39. Miri M, Kouchek M, Rahat Dahmardeh A, et al. Effect of high-dose vitamin D on duration of mechanical ventilation in ICU patients. Iran $J$ Pharm Res. 2019;18(2):1067-1072. doi:10.22037/ijpr.2019.1100 647

\section{Publish your work in this journal}

Drug Design, Development and Therapy is an international, peerreviewed open-access journal that spans the spectrum of drug design and development through to clinical applications. Clinical outcomes, patient safety, and programs for the development and effective, safe, and sustained use of medicines are a feature of the journal, which has also been accepted for indexing on PubMed Central. The manuscript management system is completely online and includes a very quick and fair peer-review system, which is all easy to use. Visit http://www. dovepress.com/testimonials.php to read real quotes from published authors. 